\title{
Memórias autobiográficas e cartas de Claire Lange: uma análise fenomenológica
}

\author{
Autobiographical memories and letters from Claire Lange: a \\ phenomenological analysis
}

\author{
Marcela Elias Santos Gonçalves \\ Marina Massimi \\ Universidade de São Paulo \\ Brasil
}

\begin{abstract}
Resumo
O objetivo desta pesquisa é o estudo da experiência de imigração descrita nas cartas e nas memórias de Claire Lange. Analisamos as vivências por ela narradas, considerando a função psicológica das cartas enquanto vínculo do imigrante com seu passado. Focamos a dinâmica psicológica e as vivências relatadas pela autora à luz do texto "O Estrangeiro" de Alfred Schütz e à luz da fenomenologia de Edmund Husserl apropriada por Edith Stein, através do olhar desta e de outras autoras, como Ales Bello e Cardoso. Nos relatos de Claire foram encontradas vivências perceptivas, afetivas, de temporalidade e vivências espirituais de fé, concomitante às categorias de análise do texto de Schütz. No que diz respeito a estas categorias, evidenciamos três grupos de vivências: as primeiras vivências do estrangeiro como recém-chegado; a crise; os mecanismos de superação da crise. Conclui-se pela possibilidade de superação da crise através do compartilhamento de vivências com a alteridade presente nas relações sociais representadas pelos destinatários das cartas, e também na dimensão transcendente do divino.
\end{abstract}

Palavras-chave: cartas; memórias; estrangeiro; fenomenologia; narrativa

\begin{abstract}
The main objective of this research is the study of immigration experiences written by Claire Lange in her memories and letters. We analyze her living experiences, taking into account the psychological function of the epistolary correspondence as immigrants' bound with their pasts. We focused on the author's psychological dynamics and living experiences based on the text "The Foreigner" by Alfred Schütz, and also on Edmund Husserl's phenomenology appropriated by Edith Stein, through the eyes of these and other authors, such as Ales Bello and Cardoso. On Claire's stories, perceptive, affective, temporality and faith-spiritual living experiences were found, according to the categories of the analysis on "The Foreigner" by Schütz. Concerning these categories, we evidenced three groups of experiences: the first living experiences as a newcomer; the crisis; the coping strategies. Our conclusion comes down to the possibility of overcoming crisis through sharing living experiences with the otherness present in the social relations which are represented by the receivers of such letters and also by the transcending dimension of the divine.
\end{abstract}

Keywords: letters; memories; foreigner; phenomenology; narrative

\section{Introdução}

Este trabalho tem por objeto documentos autobiográficos (cartas e memórias) acerca da experiência de imigração escritos por uma mulher nascida em Fleurier, na 
Suíça, em 17 de Fevereiro de 1857, Claire Reuge (que passou a assinar Claire Reuge Lange após o seu casamento com o pastor Wilhelm Gottfried Lange). ${ }^{1} \mathrm{O}$ casamento foi o marco que fez dela uma imigrante, que a retirou de sua terra natal com vistas à viagem para o Brasil.

A história de Claire se liga à de seu marido, o Pastor Lange, e à função que este desempenhou em sua igreja no território brasileiro. Wilhelm Gottfried Lange nasceu em Derwitz, na Alemanha 1858, em uma família de pastores luteranos. Foi ordenado pastor em Herrnhut - uma comunidade cristã de origem luterana pouco conhecida no Brasil, também chamada de Comunidade Morávia, Irmãos Morávios ou Irmãos Tchecos (Adami, 2003).

Dentre os ideais da Igreja Morávia estava o objetivo de fundar no Brasil uma colônia isolada preservando seus mais puros princípios cristãos. Este ideal era apoiado pela Comunidade Morávia em Herrnhut (Adami, 2003). O pastor Lange, junto de uma parte de sua comunidade (cerca de 200 pessoas de acordo com ele), decidiu-se pela imigração para o Brasil. Em março de 1886 deixou o continente Europeu para radicarse, com os membros da sua irmandade no Sul do Brasil, sabendo que, certamente, jamais retornaria à terra natal (Adami, 2003).

Em 28 de Junho, o vapor que os trazia lançou âncora no porto de São Francisco, no Sul do Brasil. O pastor procurou um pedaço de terra para a instalação de sua nova colônia. O terreno foi registrado no seu nome e ele foi chamado de "Brüdertal" - Vale dos Irmãos. Lá foi erguido um barracão, exatamente no quilômetro 18 da Estrada do Sul, onde hoje situa-se a Igreja Luterana e o respectivo cemitério. Sua esposa, Claire, chegou à colônia após um ano, em Agosto de 1887.

Enquanto viveu no Brasil, Claire Lange escreveu várias cartas para seus pais adotivos, que permaneceram vivendo na Alemanha. Através destas cartas contou o que acontecia com ela e com sua família, o dia-a-dia do casal e seu empenho de fazer de Brüdertal um lugar melhor de se viver. Suas cartas tinham entre duas e 16 páginas e algumas foram escritas durante vários dias devido às constantes interrupções das visitas ou dos afazeres domésticos. Estas cartas impressionam ora pelo seu teor poético, ora pela aguda percepção da alteridade (Adami, 2003).

Claire e o marido permaneceram em Brüderthal por 10 anos, até chegar para o pastor o convite para assumir a paróquia de Brusque, que atendia também a colônia de Blumenau. As cartas de Claire tratam também das experiências em Brusque, relatando aos pais o progresso de sua fé em território brasileiro, as mudanças ocorridas, os sonhos alcançados e as frustrações encontradas - vistas sempre como aprendizado e necessárias para o crescimento espiritual.

\footnotetext{
${ }^{1}$ Esta pesquisa teve o apoio da Fundação de Amparo à Pesquisa do Estado de São Paulo - FAPESP.
} 
Esta pesquisa tem como proposta o estudo das 13 cartas escritas por Claire e de suas memórias ${ }^{2}$. São destinadas para os seus pais - nove escritas em Brüderthal (cujas datas são: início de 1888, 19 de Março de 1888, 5 de Janeiro de 1890, 29 de Agosto de 1890, 26 de Dezembro de 1892 e 19 de Abril de 1900) algumas não constam a data específica. Quatro cartas foram escritas em Brusque (com as seguintes datas: primeiros anos em Brusque, Sábado de Páscoa de 1900, 7 de Janeiro de 1905 e 25 de Junho de 1908). Há uma carta destinada para a mãe e para a tia de Claire, datada de 28 de Março de 1905. As memórias de Claire Reuge Lange tratam da instauração da colônia de Brüderthal no município de Joinville, em Santa Catarina e compartilham os acontecimentos ocorridos em todo o período desde a sua vinda para o Brasil. Estes relatos testemunham a história ocorrida e a percepção desta de acordo com a autora.

Buscamos investigar as cartas e as memórias como relatos do processo de adaptação de uma pessoa estrangeira em um contexto de mudança. A análise dos documentos de teor autobiográfico foi realizada numa perspectiva histórico psicológica, visando compreender os processos vivenciados pela autora no novo mundo da vida. Procuramos também levar em conta a função psicológica da correspondência epistolar enquanto vínculo do imigrante com o seu mundo de origem e seu passado.

\section{O método histórico}

De acordo com Massimi (2016), os recursos metodológicos utilizados por todo historiador são as fontes e a análise interpretativa.

Entende-se por fonte qualquer testemunha perceptível sensorialmente que nos dá notícia acerca da vida humana do passado (documentos escritos, objetos, retratos, etc.). As fontes são caracterizadas por três elementos essenciais: "a natureza do material; o gênero; o conteúdo" (Massimi, 2016, p. 58).

Os gêneros, por sua vez, relacionam-se à divisão e classificação das fontes de acordo com os fins visados e os meios expressivos que se empregam. Entre os

\footnotetext{
2 As cartas e memórias de Claire nos foram gentilmente cedidas por Anette Hoffmann, descendente direta da autora dos relatos, cuja família preservou os manuscritos originais por mais de oito décadas. Estes foram ocultos durante a II Guerra Mundial, época na qual muitos documentos escritos em língua alemã foram destruídos no Brasil, por determinação oficial. Passado este período, a lata que guardava os manuscritos foi desenterrada e o seu conteúdo foi transcrito por uma das filhas e pelo genro de Claire. A família cresceu e demonstrou interesse por este material. Os escritos do pastor Lange foram publicados em 2003 e os de Claire permaneceram guardados, à espera de uma futura publicação. Nossos agradecimentos à Anette Hoffmann, bisneta de Claire e guardiã das memórias da ancestral, por tornar disponível para nós este material valioso - traduzido dos caracteres góticos para o português por Úrsula Rombach.
} 
gêneros mais comuns de fontes para o estudo histórico em psicologia estão a correspondência epistolar e as narrativas (de viagens, de celebrações, de ficção), obras poéticas, filosóficas e propriamente psicológicas. Estas aparecem como comunicação de sentido e de mundo, das relações estabelecidas num determinado período histórico, pelos seus autores. Como já dissemos, as fontes utilizadas na presente pesquisa são: um documento autobiográfico, intitulado "Memórias de Claire Reuge Lange - Primeiros tempos no Brasil" e as 13 cartas escritas por Claire em sua maioria para seus pais, algumas para os irmãos e para a tia, originárias de Brusque e de Brüderthal.

\section{Referencial interpretativo}

Interpretamos as cartas e as memórias, objeto de nossa pesquisa, detalhando a análise das vivências segundo a proposta da fenomenologia de Edmund Husserl apropriada por Edith Stein, sob o olhar desta e de autores como Ales Bello e Cardoso, que interpretam a visão de sujeito de Edith Stein como uma estrutura essencial pura constituída por vivências (Ales Bello, 2004). Além do mais, procuramos focar a dinâmica psicológica relatada pela autora, à luz do texto $O$ estrangeiro de Alfred Schütz (2010). Justificamos nossa escolha devido ao caráter fenomenológico do texto, que corresponde a um ensaio especificamente sobre o tema do estrangeiro, que se utiliza de uma análise fenomenológica dos dinamismos psico-sociais ligados à inserção do ser humano em um novo ambiente. Nos relatos de Claire foram encontradas vivências perceptivas, afetivas, vivências de temporalidade e de fé, concomitante às categorias de análise do texto $O$ estrangeiro de Schütz (2010), além de informações históricas vividas no contexto de suas narrativas.

\section{As vivências segundo Edith Stein}

Edith Stein, de acordo com o entendimento de Cardoso (2014) afirma que podemos conhecer uma pessoa através de sua obra ou dos objetos que ela nos deixa - objetos estes nos quais ela se projeta e que possuem a capacidade de nos dizer da vida particular deste indivíduo. Para ela, o objeto pesquisado - em nosso caso, as cartas e memórias - possuem traços que são humanamente universais e prevalecem, independente da cultura, do período e da região estudada. O que permite ao historiador entrar em contato com um objeto distante temporalmente, todavia suficientemente próximo, por se tratar de um fato ou acontecimento humano. 
Desta forma, salientamos a importância das cartas e da autobiografia de Claire Lange, que aparecem como vias de acesso ao seu conteúdo interior. Despontam como objetos que viabilizam ao pesquisador entrar em contato com a sua realidade vivida.

\section{Quais são as vivências?}

Em nosso estudo, procuramos analisar as vivências descritas por Claire em seu relato, dentre elas as vivências afetivas, as vivências de temporalidade (que se relacionam à maneira como a temporalidade foi por ela processada - passado, presente e futuro), as vivências perceptivas descritas nos relatos e as vivências espirituais de fé presentes nas cartas e nas memórias de Claire.

A existência de vivências de fé aparece inclusive, como mecanismo de superação da crise que se estabeleceu na autora que estudamos, advinda de sua condição de estrangeira em um novo contexto social. Procuramos analisar também as outras vivências descritas por Claire em seu relato, dentre elas as vivências perceptivas, afetivas e de temporalidade.

\section{O dinamismo do estrangeiro segundo A. Schütz}

De acordo com Schütz (2010), o indivíduo adulto é caracterizado pela permanente busca de aceitação do grupo do qual se aproxima. O autor utiliza o termo "padrão cultural de vida do grupo" a fim de designar todos os valores típicos, instituições peculiares e sistemas ideológicos que caracterizam um grupo social em um dado período da história. Qualquer membro nascido e criado neste grupo aceita e assimila o padrão cultural herdado de seus ancestrais, de suas instituições e figuras de autoridade como uma orientação inquestionável em todas as situações ocorridas no mundo compartilhado da vida social.

O estrangeiro, entretanto, desvela-se como o homem que precisa colocar em questão quase tudo que se apresenta inquestionável para os membros do grupo do qual ele se aproxima. O padrão cultural deste grupo não tem autoridade para ele, uma vez que não compartilha da tradição histórica pela qual este tem sido formado.

Num primeiro momento, o conhecimento do padrão cultural do contexto do qual se aproxima se elaborará conforme a atitude de um observador desinteressado. À medida que se aproximar, o estrangeiro irá, gradativamente, deixando de ser um observador despreocupado para tornar-se um suposto membro do grupo aproximado. Num segundo momento, o novo padrão cultural assumirá um caráter ambiental, e os conceitos originados no passado terão que ser reformulados em seus termos para se adequarem ao novo contexto. Num terceiro momento, a figura que foi internalizada 
do grupo externo existente dentro do meio social de origem do estrangeiro não mais se mostrará válida, pelo motivo de não ter sido formada com o objetivo de despertar uma reação de aceitação no grupo externo (Schütz, 2010).

Segue à descoberta de que as características do novo ambiente no qual se encontra mostram-se incongruentes com os conceitos pré-estabelecidos num passado e numa terra distante, o primeiro choque para a confiança do estrangeiro em seu pensamento habitual, trazido consigo de seu lugar de origem.

O estrangeiro torna-se consciente do surgimento de uma crise que ameaça a base de sua concepção relativamente natural do mundo enquanto estes sinais passam desapercebidos pelos membros do grupo interno, que permanecem confiantes na continuidade de seu estilo de vida habitual.

No caso da adaptação do estrangeiro ao novo grupo social, ocorre um processo contínuo de indagação do padrão cultural do grupo aproximado. Uma vez que este processo de indagação alcança o sucesso, então este padrão e todo o sistema dele decorrente tornar-se-ão algo natural, um estilo de vida inquestionável. O novo território aparecerá como um abrigo, suas características se mostrarão acolhedoras e seguras. Se isso acontecer, o estrangeiro não será mais um estrangeiro, suas questões iniciais estarão resolvidas e a crise terá cessado (Schütz, 2010).

\section{Contexto histórico}

Contextualizando o período em que a imigração do casal Lange e de seus conterrâneos ocorreu, observa-se que o movimento migratório vinha de encontro com a política brasileira, preocupada, na época, com o branqueamento da população do país e com o povoamento das regiões sulinas, com a finalidade de garantir o território e sustar a cobiça dos vizinhos platinos pela região (Alvim,1999).

A Europa encontrava-se em crise. A fome associava-se ao desespero e às condições de vida miseráveis. Emigrar foi a solução ideal encontrada. Mais de 50 milhões de europeus deixaram o continente entre 1830 e 1930 e partiram em busca de melhores condições de vida, à procura de um lugar em que pudessem ser acolhidos pelo que eram e desejavam ser (Alvim, 1999) .

A meta brasileira de atrair colonos convergia com o objetivo europeu de enviar parte de sua população para as terras americanas, de tal maneira que o Estado brasileiro acabou por modificar as leis civis que privilegiavam os católicos, a fim de facilitar a integração dos colonos protestantes norte-europeus. Na verdade, a entrada maciça de imigrantes inicia-se no final da década de 1880 , onde se consolidariam no Sul do país as comunidades alemãs (Alencastro \& Renaux, 1997). Tal qual Claire e o 
pastor Lange, diversos europeus passaram por este processo, e estas vivências constituíram uma parte da formação de nosso país.

\section{Análise das vivências}

\section{Primeiras vivências do estrangeiro como recém-chegado}

Nossa pesquisa procura abordar a situação de Claire Lange, imigrante europeia no Brasil. Portanto, procuramos identificar as suas tentativas de ser assimilada ao grupo do qual se aproximou.

Em seu ensaio, Schütz (2010) menciona que o estrangeiro, quando de sua chegada no novo contexto sócio-histórico-cultural, não compartilha das suposições básicas compartilhadas pelos membros da nova pátria. Para ele, o padrão cultural do seu grupo de origem continua sendo a sua referência inquestionável. Naturalmente, ele começa a interpretar seu novo ambiente social de acordo com o seu pensar habitual. Dentro do esquema de referência de seu grupo de origem trazido por ele, existe uma ideia preconcebida sobre o grupo aproximado e seu padrão cultural - ideia esta que se revelará inadequada.

O processo acima descrito foi observado na leitura das cartas e memórias de Claire Lange. Ela chegou ao Brasil trazendo consigo o padrão cultural europeu no qual havia sido criada e formada enquanto mulher. Este padrão mostrou-se disfuncional em solo brasileiro e houve um descompasso entre os seus hábitos e costumes e o novo posicionamento exigido dela na nova terra. Como não compartilhava das suposições básicas propagadas no padrão cultural brasileiro, questionou estas práticas; assim, desencadeou-se em sua experiência uma situação de crise.

\section{1. "As mais diversificadas sensações": aproximação da nova realidade}

Claire chegou em um navio em 1887 e aportou em São Francisco, na região sul do Brasil. Após 20 anos, procurou descrever em suas memórias suas primeiras impressões e as vivências perceptivas que lhe ocorreram quando de sua chegada naquele novo país, naquela nova realidade, naquele novo contexto no qual passaria o resto de sua vida. Observa-se a coexistência de elementos descritos no texto de Schütz - especificamente a atitude de observador - associados a vivências perceptivas. O relato de Claire das próprias vivências aponta para o impacto da nova realidade, que é desvelado na percepção do meio e nas sensações por ela desencadeadas. Associam-se às vivências características da condição de estrangeiro citadas por Schütz, o desvelamento de vivências complementares: vivências afetivas, 
além de vivências de temporalidade e vivências espirituais, especificamente de natureza religiosa. Naturalmente, esta atitude de ligação com o transcendente a acompanhou em todos os momentos de sua existência. Especificamente, como procuramos enfocar o período no qual redigiu seus escritos, desde a chegada na nova pátria, passando pelos momentos de crise e de ruptura, até sua adaptação no novo território. E como nos lembra Edith Stein (2018), exceto para Deus, cujo conhecer é um saber eterno, o conhecer humano é algo inerente àquilo que começa, à apreensão inicial de um saber. Foi exatamente esta progressão humana que Claire vivenciou.

Entretanto, é importante considerar que Claire escreve estas memórias 20 anos depois de sua chegada, tendo já superado a condição inicial de estrangeira e a crise dela decorrente. Seus relatos remetem à reflexão de suas vivências, e portanto, à uma re-significação de tudo que a afetou no momento de sua chegada. A seguir, apresenta-se um trecho da descrição da cidade de São Francisco, contida em suas memórias:

A cidade de São Francisco está maravilhosamente situada paisagisticamente. Nas encostas das colinas e morros estão construídas as casas, que, com sua pintura branca, destacam-se lindamente do fundo escuro das verdes florestas. Na ampla enseada estão espalhadas uma série de ilhas. Batidas o ano inteiro pelas ondas do mar, que apesar de seu trabalho incansável, nenhum mal Ihes podem causar. Porém, quem for suficientemente ousado para entrar na cidade, verá em pouco tempo sumir o romantismo. A gente tem a impressão de encontrar-se numa cidade em ruínas, pois na maioria se vêem só altos muros com bem pequenas janelinhas, e entre elas cá e lá telhados e cumieiras de formas diversificadas.

Pode-se observar neste trecho o impacto que a nova realidade causa em nossa autora, bem como as vivências afetivas despertadas pelo novo lugar em que chegara. A energia vital liberada no momento do primeiro contato com o Brasil, assegura ao relato de Claire uma riqueza de detalhes e uma descrição bastante específica das pessoas e da cidade. A mirada intencional de sua atitude de observadora direciona sua atenção para os objetos que se encontram "de fora" de sua consciência. A vivência perceptiva de Claire apreende os objetos que aparecem na nova realidade que a ela se apresenta. Salienta-se que, em seu relato, não há como separar os elementos da atitude de observador com as vivências advindas desta atitude, uma vez que nos referimos a Claire como pessoa, ou seja, como a uma estrutura essencial pura constituída por vivências, conforme a definição de Edith Stein mencionada por Ales Bello (2004). A vivência perceptiva é sempre direcionada para o ambiente, constituída pelas sensações e pelas vivências afetivas, que demonstram como aquela realidade afeta o indivíduo. 
No trecho a seguir, Claire procura relatar a sua situação e as vivências despertadas neste contexto, ainda no navio, quando observou pela primeira vez seu noivo, que se aproximava em um pequeno barco:

\begin{abstract}
Eu estava de pé no convés, com as mais diversificadas sensações. Meus olhos observavam, sim, o movimento colorido à minha frente, mas no fundo apenas superficialmente, pois naquela confusão procuravam pela figura do meu noivo, que havia feito a travessia um ano antes de mim, para preparar o ninho na selva como religioso de uma comunidade de emigrantes, e que agora viria aqui para buscar-me. (...) Assim eu tive bastante tempo para, olhando de cima, olhar o meu noivo e observar sua aparência após um ano de vida na selva. Ele havia ficado mais magro, mas no mais parecia o mesmo. Apenas seu terno estava com aspecto de selva, e eu tenho de reconhecer que fiquei um tanto assustada com o tom avermelhado adquirido por seu chapéu, e com o tecido de seu paletó luzindo na mesma tonalidade. Naquele momento pensei: "É bom que eu venha, eu Ihe ajudarei bastante a cuidar de si." Ilusão! Pura ilusão! Muito em breve eu mesma aprenderia com que aparência a gente fica após cavalgar em picadas, durante 2 dias, em caminhos do mato.
\end{abstract}

No relato acima citado emergem vivências perceptivas advindas da atitude de observação. Como este trecho foi tirado de suas memórias, e Claire se encontrava em um momento específico rememorando e re-significando as suas vivências, observa-se a ressalva por ela feita ao se referir ao fato de que naquele momento ela se enganou, pensando que com sua vinda o pastor seria mais bem cuidado. Dentro de pouco tempo ela adentrou a realidade e compreendeu que a experiência vivida naquele lugar não viabilizava uma aparência cuidadosa, como a que ela estava acostumada e pensava ser possível manter.

Claire demonstra, em seus escritos, uma expectativa acerca do novo contexto derivado de seu padrão cultural de referência e a sua tentativa de se adaptar a este novo contexto se utilizando das ideias e dos conceitos formados em sua pátria, dos aprendizados trazidos da Europa e das condutas funcionais e efetivas vividas naquele lugar.

\title{
1.2. "É claro que aqui também tudo é bonito, mas mais bonito é lá em casa...": padrão cultural de referência
}

Como descrito por Schütz (2010) em seu ensaio, o padrão cultural de referência formado no grupo de origem acompanha o indivíduo ainda que este se desloque e vá viver uma nova realidade. Ainda em suas memórias, Claire descreve a cidade de Joinville, para onde foi no dia seguinte de sua chegada. Na narrativa, o modelo de 
referência é o padrão cultural de seu grupo de origem, através da comparação da cidade recém-conhecida com a realidade alemã:

Joinville é uma cidadezinha bonitinha, e, com suas casas simpáticas cercadas de bem cuidados jardins, dá a impressão de ser um pequeno balneário alemão. Nas ruas ouve-se falar quase só alemão, pelo que um alemão em pouco tempo se sente em casa aqui, se puder esquecer $o$ grande mar que o separa da pátria. É claro que, observando melhor, chama a atenção a vegetação estranha. Não é uma alameda de tílias pela qual caminhamos, e sim uma majestosa alameda de palmeiras reais. Entre as casas se vêem os mais diversos tipos de palmeiras, e laranjeiras com sua folhagem verde e frutos amarelo-dourados. Nas varandas das casas vêem-se as mais maravilhosas folhagens e nos jardins floresce uma multiplicidade de flores, em quantidade esbanjadora o ano inteiro. É um eterno verdejar e brotar, e nada na natureza lembra morte. Mas, com o tempo, esse quadro não nos satisfaz mais, porque não condiz com a realidade, com a vida. Eu sinto falta do outono, com seu tapete crepitante, do inverno, com seu espesso manto branco e cintilante cobrindo tudo.

Observa-se, no relato de Claire, a comparação de Joinville com um balneário alemão, e a sua tentativa fracassada de aproximar a nova realidade com as lembranças da terra natal, marcadas pela impossibilidade da semelhança da vegetação. Por mais que a cidade brasileira remeta à cidade alemã, a vegetação para ela "estranha" - evidencia a diferença, a distinção, a disparidade entre ambas as realidades.

Outro aspecto interessante que aparece é que, por mais que o novo contexto e o aspecto inusitado da natureza pareçam bonitos para a autora, a presença deles não preenche uma lacuna deixada pela ausência dos elementos constitutivos da pátriamãe. Quando Claire menciona que este aspecto não condiz com a realidade, ela se refere à realidade europeia, à realidade vivida por ela por todos estes anos, à sua experiência de vida e às suas vivências individuais. O seu padrão cultural de referência é o alemão. E é através destes óculos que ela irá enxergar o lugar no qual chegou, e também o grupo que nele habita.

Misturam-se às vivências de estrangeira, vivências afetivas e de temporalidade, que acabam despertando em Claire o sentimento de saudade da terra natal:

Depois a natureza despertando em maio. Como tudo germina e brota da terra! As mais delicadas cores surgem nas árvores e arbustos. Os bichinhos despertam para uma nova vida, fortificados e refrescados. Agora, 10 anos mais tarde, meus olhos têm saudade dessas paisagens da pátria. Eu quero novamente ver uma rua congelada, com os rostos alegres dos patinadores, quero ver crianças de escola com seus narizinhos vermelhos de frio, que antes de entrarem na sala de aula precisam primeiro sacudir a neve de seus casacos. Muita coisa da pátria 
eu quero rever. Ainda que outros, que talvez nunca viram os trópicos sonhem com a exuberância de suas árvores, flores e pássaros. É claro que aqui também tudo é bonito, mas mais bonito é lá em casa, onde neva e faz frio, onde todas as folhas murcham e novamente brotam verdejantes.

Neste trecho encontram-se vivências de temporalidade, caracterizadas pelas lembranças da terra natal, além de vivências perceptivas e afetivas. Observa-se a dor advinda do sentimento de inadequação da nova realidade com aquela na qual a autora estava acostumada. Novamente, apreende-se que por mais bonito que pareça o novo grupo e o novo país no qual Claire vive, as impressões e os sentimentos despertados não se igualam àqueles vividos no ambiente no qual nasceu, cresceu e se tornou mulher.

Prosseguindo, observam-se as vivências perceptivas e afetivas de Claire, quando da descrição do primeiro contato com a casa paroquial, na qual viveria com o pastor. O assombro e a surpresa equiparam-se às impressões despertadas pela Igreja também:

Eu fiquei parada pensativa. Isto portanto era o meu novo lar. Eu o via pela primeira vez. Certamente eu não havia criado ilusões e estava preparada para ambientar-me nas condições mais simples que fossem. Mas o quadro que aqui se apresentava aos meus olhos era algo tão novo, tão estranho, tão inesperado, tão simples e ao mesmo tempo tão grandioso, que eu precisei de algum tempo para me recuperar.

Depreende-se da descrição de Claire, a lembrança de sua atitude de observadora impactada em um primeiro momento pela novidade e pela complexidade da realidade que para ela se apresenta. Analisando melhor, pode-se dizer que os elementos do padrão cultural de referência (o europeu) não são suficientes, no sentido de que por mais que ela houvesse se preparado para se adaptar às "condições mais simples que fossem" - em suas próprias palavras, não havia como anteceder o impacto da nova realidade, tampouco preparar-se para lidar com ela de antemão. O novo fato que se revelou à autora a afetou a ponto de exigir dela tempo para assimilar o ocorrido.

Há momentos nos quais Claire compara o clima do Brasil com o da Alemanha, estabelecendo uma aproximação entre ambas as pátrias:

Nessa época, muitas vezes fazia frio. É, também no Brasil pode-se sentir frio, no inverno, pois o termômetro podia descer até 2 graus acima do ponto de congelamento.

Neste aspecto, observa-se a correlação elaborada pela autora do relato entre a realidade da qual havia vindo e a nova realidade que se desvelava a ela. Encontra-se ainda, nos relatos de Claire, a dificuldade de se adaptar quando o seu costume a 
levaria a agir de modo diferente, de acordo com o instituído pela sua cultura. Uma mudança acaba exigindo um novo posicionamento diante do mundo e do universo valorativo formado pelo estrangeiro:

A um europeu parece bastante estranho, quando pela primeira vez tem de passar sua festa de natal nos trópicos, e com certeza dificilmente consegue colocar-se logo no devido clima emocional. O calor faz-se sentir mais desagradável justamente nessa época, e as pessoas ficam moles e cansadas: a comunidade da igreja que, em B. (Brüderthal), na noite de natal havia se juntado em torno da árvore folhosa tirada do mato e enfeitada festivamente, estava constantemente ocupada em abanar-se com panos para proporcionar-se ar fresco e enxugando o suor da testa. Apesar disso gosto de lembrar-me daquele tempo, quando ainda festejávamos essa festa com nossa pequena comunidade, isolada do resto do mundo.

No trecho acima Claire menciona a dificuldade de se adaptar ao clima da nova região e o esforço exigido de seu grupo para comemorar a festa cristã em um lugar tão distante e diferente daquele no qual foram passados todos os natais até então. Rompendo com o costume e a tradição do Natal europeu, o ambiente tropical exigiu uma reorganização dos esquemas tradicionais. Ao final do espanto, Claire chegou à seguinte conclusão:

Quando então ressoaram os cânticos de natal das crianças, do coral da comunidade, com acompanhamento de harmônio e de violinos; quando foi lida a antiguíssima e sempre nova história do nascimento do Salvador; quando as crianças, com olhos brilhantes, vinham à frente para, de acordo com a idade, declamar uma frase ou um verso, podíamos esquecer que vivíamos na selva. Não era o mesmo Deus a quem festejávamos nessa noite, tanto na velha como na nova pátria?

Através da aproximação da nova realidade com a antiga, da procura de semelhanças entre o novo contexto e o anterior, da consideração de que se comemorava a mesma data em ambas as culturas, Claire consegue estabelecer uma comparação e aproximação entre os dois mundos da vida. Embora o ambiente físico fosse realmente muito diferente, ela vivia uma única realidade - que foi trazida consigo e inserida no novo campo social: "a selva". Utilizando-se de suas vivências espirituais (fé), conclui que independente do local geográfico e do grupo no qual se encontra, existe a unidade de um mesmo Deus - presente tanto em solo europeu quanto em terras americanas.

Neste momento observa-se o despertar da autora para a nova realidade através da comparação com o seu passado; entretanto, ela assume um novo posicionamento: demonstra a capacidade de encontrar a beleza em seu novo ambiente. A 'estrangeira' Claire começa então a se ambientar no Brasil e o pensamento habitual, formado na 
Europa, mostra-se falho e insuficiente para encarar esta nova realidade. 0 desdobramento da vida neste novo contexto requer uma mudança de postura, desenvolvida com a finalidade de se adaptar no novo ambiente, de fazer da nova moradia um lar e de se sentir em casa neste novo país.

\section{3. "Aceitar a ideia de que não estamos em casa é muito difícil, para mim é muito desagradável": o caráter disfuncional do pensamento habitual}

Diante da nova realidade que se desvela para o estrangeiro, o seu pensamento habitual acaba se revelando inadequado. Ao se deparar com o novo contexto ambiental e cultural vivenciado, este sistema de valores e esta maneira de interpretar o mundo requer um reposicionamento, que desencadeia o aparecimento de uma atitude reflexiva, portanto, de uma vivência do espírito com caráter intencional, à medida que a consciência se coloca diante de um ato específico com a finalidade de interpretá-lo. Claire relata, em uma de suas cartas escrita em 1888 para seus pais e irmãos, a dificuldade de aceitação deste novo contexto e da sua nova configuração existencial:

Mas aceitar a ideia de não estar em casa nos é muito difícil; principalmente para mim é bastante desagradável.

Embora haja dificuldade em aceitar a nova realidade que a ela se apresenta, a autora tem consciência da necessidade de permanecer neste novo contexto e apesar do desagrado, continuará se esforçando até assimilar os dados reais que lhe permeiam.

Em carta datada de 1892, escrita para seus pais, Claire demonstra uma visão pré-concebida dos brasileiros, uma maneira de classificá-los previamente, antes de entrar em contato com a realidade vivida por este povo:

Em todo caso, muitas pessoas lá são gente muito rude, tanto, que na Europa não se pode nem fazer idéia. Na Europa, no ambiente culto, eles vivem constrangidos, mas aqui, facilmente a pessoa se solta, mostrando-se como ela é na verdade. Isto já está no clima, que a gente fica fisicamente e infelizmente também espiritualmente bastante enfraquecido.

No trecho acima mencionado pode-se observar o caráter disfuncional da visão formada acerca dos brasileiros, e o despreparo da atitude estigmatizante, que acaba atribuindo a estes a falta de auto-controle, justificada pelo clima tropical. Esta aproximação do povo brasileiro partindo de uma imagem formada no padrão cultural de origem do estrangeiro pode ser observada em outra carta, datada de 1900, 
destinada também aos pais, na qual Claire procura descrever a eles o comportamento da mulher brasileira e as suas características. A seguir, apresenta-se o seu relato e as impressões que lhe despertam a mulher brasileira:

Se vocês repararem na data de minha carta, certamente se admirarão de como eu, uma dona de casa alemã, me sento hoje, ainda por cima de manhã, para escrever. Vocês pensarão que eu me tornei uma das brasileiras legítimas, que o ano todo não se preocupam com a manutenção da casa, enquanto seus maridos Ihes fazem o café de manhã cedo e os quais também cuidam das crianças. Uma brasileira assim na verdade não se preocupa, pois a gente as vê em geral a qualquer hora do dia de braços cruzados, sentadas à janela, olhando para o mundo. No inverno ficam acocoradas junto ao fogo e de tempos em tempos empurram um pedaço de lenha, abrem cá e lá a panela de feijão, com um olhar de seus olhos escuros examinam a sopa escura espartana, fecham a panela com a mesma indiferença e voltam a olhar sonhadoras para dentro do fogo.

A brasileira comum não procede de modo diferente. O cabelo, que geralmente é lindo, preto escuro e um pouco ondulado, só é arrumado quando alguma vez tem de sair ou quando espera visita. Avental é coisa que uma mulher assim não conhece. Uma descuidada saia longa Ihes pende sobre as pernas e é usada tanto tempo, até que se acabe em trapos. Assim também uma blusa solta, restos de antigo esplendor. Envolta nesses farrapos, uma brasileira se movimenta como uma rainha, em porte e movimentos, em seu ambiente caseiro, superior a tudo e soberba como se nada Ihe importasse. Apesar dessa despreocupação, elas envelhecem cedo e o rosto se cobre muito cedo com uma infinidade de rugas. A mim sempre provoca riso o seu ar de importância, quando elas se visitam mutuamente. E ainda mais, como se parece uma sociedade de tais brasileiras? Elas aparecem altamente enfeitadas, cheias de rendas e fitas sobre cores berrantes. Após os primeiros cumprimentos, em que elas se abraçam muito cerimoniosamente, encostando rosto em rosto, com beijos no ar e três tapinhas nos ombros, sentam-se rígidas como estátuas de mármore, sobre os bancos ou cadeiras quando estes existem, rente às paredes da sala, e se olham umas às outras, trocando vez por outra um sorriso cheio de dignidade.

Pode-se observar a divergência entre a realidade das mulheres brasileiras e o olhar de Claire destinado a elas. Em sua carta, ela descreve as mulheres como desocupadas e despreocupadas com o cuidado dos filhos - formulando um juízo decorrente de uma generalização quanto a uma suposta atitude de descaso com a família e com o lar no comportamento feminino brasileiro. A descrição de Claire é disfuncional na medida em que ocorre uma generalização da conduta humana. Ademais, ela se aproxima do grupo brasileiro como uma estrangeira, como um membro externo. O seu olhar é enviesado. Consequentemente esta forma de abordar as suas novas conterrâneas e esta visão distorcida sobre a sua natureza, acabará dificultando o acesso a elas e a adaptação no território do qual elas se originam. 
Com estes relatos conclui-se, pois, que as vivências lembradas e relatadas por Claire remetem ao caráter disfuncional do pensamento habitual do estrangeiro diante da nova realidade que a ele se apresenta. À medida que vai vivenciando este novo contexto, ele compreende que o seu sistema de valores trazido da terra natal não é suficiente para assegurá-lo no novo território e que existe, portanto, a necessidade de alteração de alguns pressupostos. Ao entender isso, o estrangeiro percebe o aparecimento de uma ameaça na base de sua concepção relativamente natural de mundo, que interrompe o andamento da rotina habitual e demanda condições de transformação na consciência. Instala-se assim a crise, que destrói o sistema corrente de relevâncias formado até então.

\section{A crise: vivências de choque de confiança no pensar habitual}

De acordo com Schütz (2010), a descoberta de que as situações ocorridas no novo ambiente se diferenciam da expectativa criada na terra natal, consiste, frequentemente, no primeiro choque do estrangeiro em seu pensamento habitual. Todo o sistema de interpretação corrente vivenciado até então torna-se invalidado. Não pode, portanto, permanecer sendo utilizado dentro deste novo contexto. A nova realidade exige deste um reposicionamento e uma reestruturação de seu olhar. Neste ínterim, acaba ocorrendo um deslocamento social do estrangeiro, e ao se aproximar, resta a ele traduzir os termos e os códigos de conduta do novo padrão cultural nos termos do padrão cultural de seu grupo de origem.

\section{1. "Com o tempo fui me acostumando mais e mais às circunstâncias...": o salto da plateia para o palco}

Em suas memórias, no relato sobre a travessia feita de Joinville à Bruderthal local no qual se radicariam, onde Claire viveria por dez anos junto do pastor, ela começa a tomar consciência da necessidade de deixar de ser uma mera espectadora, de não se limitar apenas à observação da realidade, mas de começar a agir no mundo para transformar esta realidade e ser por ela transformada:

Mas voltemos à nossa viagem! Em pouco tempo terminou o caminho trafegável. Nossos cavalos haviam chegado ao seu destino, mas nós ainda não, ou seja, agora cabia-nos usar as pernas, e muitas vezes ainda também os braços. (...) Ali eu cheguei à conclusão de que, uma esposa de pastor destinada ao Brasil, deveria, antes de sua viagem, fazer um curso na nobre arte de equilibrista em cordas, para que, ao transpor rios em pontes sem corrimão, pudesse mostrar mais habilidade do que eu. 
Quando se viu diante desta realidade que a ela se apresentava, foi preciso que Claire reagisse com o repertório que possuía. Ela não estava preparada para tamanho esforço físico, tampouco apresentava habilidades para tanto, mas foi com o tempo e com a prática que foi aprendendo a conviver com a nova realidade.

Uma vez ambientada no novo território, aparecem as dúvidas e os receios processo natural quando se deixa a sua pátria para viver em terras distantes.

Mas voltemos à casa e à cozinha. O que deveria eu cozinhar? O que me adiantava que, durante a viagem no navio, houvesse estudado com tanto empenho as receitas de Henriette Davidis e de ter já preparado o cardápio para a primeira semana? Para poder fazer um bife ou um assado, precisa-se de carne fresca; aqui, porém, por muitos anos não havia ali um açougue, bem como nenhum padeiro, não havia leite $e$ nem manteiga. (...) Minhas vizinhas - se é que assim se pode chamálas, considerando a distância - socorreram-me nos primeiros dias com sua ajuda, seus conselhos, com banha, ovos e carne conservada.

Observa-se que, por mais que Claire houvesse tentado se preparar para viver no Brasil, as receitas culinárias aprendidas na Europa assumiram um caráter disfuncional, uma vez que não existiam estes ingredientes na nova terra. Foi preciso a ajuda dos outros que aqui viviam. Com o tempo, Claire se ajusta melhor às situações:

Com o tempo fui me acostumando mais e mais às circunstâncias e também aos cuidados do campo, de que inicialmente eu nada entendia. No galinheiro encontrei, na minha chegada, um galo e uma galinha. Como fiquei contente quando, pela primeira vez, ouvi nosso galo cantar. Pareceu-me que nunca, desde a criação do mundo, um galo havia cantado tão alto e bonito.

Neste trecho retirado de suas memórias, observa-se o processo de aprendizagem desencadeado pelo contato com a realidade, através de vivências perceptivas - que coexistem junto de vivências de temporalidade e afetivas. À medida que assume o papel principal em sua existência diante do novo ambiente, elementos afetivos começam a aparecer. Em sua vivência perceptiva, desencadeada pela sensação de escuta do canto do galo, Claire se sentiu privilegiada e projetou elementos internos naquela situação, interpretando aquele canto como o mais bonito que já ouvira.

Ao chegar, ela se recordava da pátria como aquela que possuía a natureza mais bonita. À medida que se adapta ao novo contexto, passa a enxergar a beleza existente neste e a se identificar com alguns dos elementos presentes, como ocorreu ao ouvir o coral natalino na selva e ao ouvir o galo cantar. Conforme o passar do tempo, a nova realidade foi então sendo melhor assimilada por Claire. 


\section{2. "Um pedacinho de pátria alemã em meio à selva.": a transformação do novo padrão cultural em caráter ambiental}

Com a atitude de protagonização no novo ambiente e a revelação de que o padrão cultural trazido do grupo de origem seria disfuncional, a realidade do Brasil foise impondo e sendo absorvida pela imigrante através de indagações frente ao desconhecido, visando confrontar o sentimento de estranheza e de familiaridade. Nas memórias, Claire relata a maneira com a qual procurou trazer um pouco da sua história pessoal, dos seus familiares e das suas lembranças para o novo contexto quando elabora comentários acerca da função das cartas escritas pelos familiares e trazidas junto dela para serem abertas no dia de seu casamento:

Nós lemos as cartas que eu havia trazido comigo da pátria e que só deveríamos abrir no dia do casamento. Elas continham votos de bênçãos e saudações dos queridos pais, de parentes e de amigos. Foram escritas com olhos lacrimejantes, e com olhos lacrimejantes foram lidas, mas nós também nos sentíamos reconfortados e fortalecidos, na certeza de que as orações de nossos entes queridos nos acompanhariam e nos ajudariam a superar a saudade de casa.

No trecho acima citado pode-se observar, através da descrição da vivência afetiva da autora, o processo de familiarização no ambiente estranho, ocorrido através da mediação das cartas escritas por seus familiares e lidas sob o impacto de forte emoção no novo contexto. Partindo do conceito trazido por Edith Stein, trabalhado por Cardoso (2016), pode-se afirmar que Claire discorre sobre o sentimento de sentir-se acolhida pelos familiares através da leitura das cartas. Este acolhimento é descrito por Stein (2018) como "descansar em Deus" e ocorre não apenas quando a energia vital é restabelecida através deste contato com o transcendente, mas inclusive quando estamos diante de outras pessoas que nos ofertem descanso e amor. Esta vivência têm a capacidade de proporcionar a reposição da energia vital de uma pessoa em estado de esgotamento.

Em carta escrita em março de 1905 para a mãe e a tia, Claire novamente aponta a importância da correspondência em seu processo de adaptação na nova pátria e o seu valor para se fortalecer diante do novo ambiente realidade:

Vocês novamente me colocaram água na boca, com sua carta, querida e longa, que recebi após tanto tempo. Eu quero receber novas notícias de vocês e por isso venho novamente mendigar, bem ao jeito de mendigos, incansavelmente, ainda que seja só por um pouco.

As cartas trocadas fornecem à Claire o sentimento de segurança e de pertença, originado de seu grupo de origem, já que receber notícias das pessoas que ama e de 
como a vida tem se desdobrado na pátria por ela deixada constituem um elo entre a realidade distante e passada e realidade presente, vívida e futura.

Em carta datada de 1890, destinada a seus pais, Claire discorre sobre a vivência afetiva e o impacto das cartas, descrevendo a percepção que elas causam e o conforto que lhe oferecem, comparando-as com um bálsamo, capaz de consolar e diminuir a aspereza da realidade:

Querida Mãe, agradeço mil vezes pelas receitas; também à Tia Ida, Papai e por todas as queridas cartas. Elas são aqui, na selva, um verdadeiro bálsamo para nós.

Dentre os mecanismos utilizados por Claire para se familiarizar na nova pátria e para confrontar a estranheza, salienta-se, além da troca das cartas, o esforço para tornar o novo ambiente mais próximo daquele deixado para trás, através da utilização de objetos e enfeites trazidos da pátria e de retratos dos entes queridos no novo lar:

Eu havia trazido da Europa bastante pano para forração de móveis, com o qual agora pude revestir os grosseiros móveis feitos de caixotes. Assim, havíamos nos proporcionado um pedacinho de pátria alemã em meio à selva. Das paredes nos olhavam os retratos de nossos entes queridos; sobre mesas, cômodas, sofá, estavam lembrancinhas pintadas, bordadas, costuradas, que haviam sido preparadas por mãos carinhosas. Tínhamos arranjado nosso ninho de modo bem agradável e caseiro, e não invejávamos a nenhum senhor feudal por seu palácio.

Observa-se o contraste existente entre os móveis construídos em sua nova moradia, rudes, feitos de caixotes de madeiras, diante dos tecidos finos de revestimento trazidos por Claire da Europa. Mas foi através destes símbolos, como o pano que forrou os móveis e os objetos que enfeitaram a decoração, que a estrangeira conseguiu se identificar com o novo espaço que ocupava e com a nova realidade que a envolvia.

Ao viver cada nova experiência proporcionada por este novo lugar, Claire procurou se adaptar e reconstruir seu mundo, mas esta realidade nova em que estava não era nem confortável, tampouco facilitadora. Pelo contrário, muitas vezes, apresentava-se como um campo de aventuras, exigindo que Claire fosse forte tanto física quanto psicologicamente para enfrentar seus desafios e dificuldades.

\section{3. "Eu estava amedrontada": nova realidade - campo de aventuras}

De acordo com Schütz (2010), quando encontramos no ambiente algo diferente do que estamos habituados, automaticamente iniciamos um processo de indagação originado desta estranheza. Isto ocorre também com o estrangeiro que chega em um 
novo mundo, iniciando-se um processo de indagação contínuo do inusitado padrão cultural do grupo aproximado, com vias à adaptação na nova realidade e à promoção do ajuste social do indivíduo.

Pode-se observar nas memórias de Claire seu relato diante da insegurança gerada pela nova realidade - através da vivência afetiva do medo:

pois eu não conseguia vislumbrar como seria minha vida futura, e eu estava amedrontada. Tudo me era tão novo, tão estranho, e o que estava à minha espera poderia ser ainda mais estranho. (...) Uma porção de dificuldades e confusões estavam por vir: eu o sabia, e não me preocupava muito com isso. Desconfortos e incômodos podem ser superados com indiferença, até com humor.

No trecho acima citado, Claire transcreve a sua consciência a respeito da novidade que a aguardava, seu receio diante do porvir e a estranheza causada pela nova realidade.

Além da realidade que se apresentava diante dos próprios olhos desvelar-se uma aventura e trazer consigo a exigência de uma reconstrução no olhar, ocorreu à Claire uma vivência de crise dentro da própria crise na qual ela estava instalada. Como estrangeira, consciente de que o seu pensar habitual não serviria como base para se orientar naquele novo ambiente - que exigia dela um reposicionamento e uma nova visão de mundo, Claire também passou por uma crise quando teve a casa em que morava incendiada. Estava ausente com o pastor, fora acompanhá-lo na realização de um casamento, e quando voltaram, encontraram o lar em chamas. A casa na qual iniciavam seu processo de familiarização com a nova pátria fora incendiada. Claire descreve sua angústia diante do ocorrido:

Eu vi que meu marido, a quem haviam conduzido à parte, de repente ficou pálido. Uma forte tremedeira tomou conta de mim e o sangue parou em minhas veias. "O que foi? O que aconteceu?" Meu marido, que me havia tomado pelas mãos, conduziu-me adiante e me contou que nossa recém construída casa estava em cinzas e ruínas desde o meio-dia, e que quase nada mais possuíamos de nossas coisas, além das roupas que estávamos usando. - Meus pés teriam virado chumbo? Só com muita dificuldade eu pude ir me arrastando. Eu temia, com pavor, a visão do local de incêndio, e teria preferido correr de volta, selva a dentro, já que eu não tinha mais um lar. Meu marido puxou-me lentamente consigo. Ele estava silencioso e controlado, apesar de ter perdido tanto quanto eu!

Salienta-se na descrição de Claire o processo de crise alavancado pela destruição do local no qual ela estava investindo seus esforços psíquicos para superar a crise gerada por sua situação de estrangeira. Ela narra a presença de uma vivência que consome a energia vital sem renová-la, esgotando seus recursos psicológicos e 
enfraquecendo sua disposição física. O impacto da notícia a afeta de tal maneira que a própria corporeidade é envolvida: os seus pés teriam virado chumbo e em seguida ela foi "se arrastando" com muita dificuldade. Observa-se, neste trecho, a vivência afetiva da estranheza. Em suma, o novo ambiente se revelou como um campo de aventuras, abordado num processo de indagação constante e vivenciado muitas vezes como um problema a ser solucionado.

\section{Mecanismo de superação da crise}

Para Schütz (2010), quando um ser humano se depara com um fenômeno até então desconhecido por ele, e que, portanto, ressalta da ordem do comum em seu sistema de valores, inicia-se o processo de indagação. Quando se cumpre este processo, aquele que anteriormente foi um fato estranho e um problema enigmático é transformado em um elemento a mais do sistema de conhecimento do indivíduo, ampliando desta maneira, o seu estoque de experiências. No caso de Claire, recémchegada no Brasil, pode-se observar que ela se submeteu ao processo de indagação quando instaurada a crise, e que este processo foi superado através de sua experiência religiosa, de sua vivência espiritual da fé. Foi no transcendente que Claire encontrou a solução dos problemas enfrentados no novo contexto e foi em seu relacionamento estabelecido com o sagrado que ela conseguiu forças para superar a crise profana ocorrida neste mundo físico e material.

\section{1. "Jesus, segue à minha frente": a experiência de fé vivida e relatada por Claire}

A vivência da fé como alimento da força vital para superar a experiência de crise e a angústia dela originada, encontra-se presente em todas as cartas de Claire e em vários trechos de suas memórias. Tal vivência assume as facetas de experiência da ligação com o sagrado, da entrega de sua vida para um Deus maior que cuidaria de tudo, a confiança de êxito na aventura vivida na selva, garantida pela crença de que quando se tem um Salvador, todos podem se salvar. Logo no início de suas memórias, encontra-se referência à experiência de fé, quando compartilha com o leitor as lembranças de seu casamento, celebrado logo após a sua chegada no Brasil:

Como foi bem escolhido o texto que serviu de base à cerimônia do nosso casamento: "Nós caminhamos na fé, e não na espuma." E como nos tocou o coração a apresentação do mesmo. Após a cerimônia, o Grupo de Canto de Brüderthal apresentou algumas frases de bênçãos, das quais mais me marcaram e permaneceram na memória as conhecidas palavras "Jesus, segue à minha frente", que muitas vezes se tornaram 
para mim uma prece que brotava de meu coração durante as muitas impressões novas naqueles dias. (...) Como nos sentiríamos solitários e órfãos em tal situação no dia do casamento, se não tivéssemos o nosso Salvador! "Nós caminhamos na fé, e não na espuma", isto valia também para as circunstâncias exteriores, pois eu não conseguia vislumbrar como seria minha vida futura, e eu estava amedrontada. Tudo me era tão novo, tão estranho, e o que estava à minha espera poderia ser ainda mais estranho. Mesmo assim, "Jesus, segue à minha frente", ainda que na selva. Eu não achava que as exterioridades pudessem abalar-me muito. Uma porção de dificuldades e confusões estavam por vir: eu o sabia, e não me preocupava muito com isso. Desconfortos e incômodos podem ser superados com indiferença, até com humor. Mas se somos forçados a viver tais condições dia a dia, ano após ano, só Deus poderá dar-me a força para não fraquejar e ser impaciente.

Observa-se no trecho acima transcrito a força e a segurança advindas do texto e do cântico que orientaram a autora em momentos de temor do desconhecido. Ciente das dificuldades que se apresentariam em sua nova realidade, Claire apegou-se à certeza de que não as enfrentaria sozinha, acrescentando que poderiam ser vividas até mesmo com humor, desde que se estivesse na presença de Deus. Na descrição mesclam-se vivências afetivas e perceptivas de sua realidade presentes em seu testemunho de fé. Pode-se observar o fenômeno de renovação das forças e da energia vital ocorrido através da vivência espiritual de sua experiência religiosa, sustentando nela a certeza de que o seu Deus a protegeria e acompanharia sempre por mais desagradável que fosse a situação na qual se encontrasse e por mais estranho que pudesse ser a nova realidade que a circundava.

A vivência da fé também se faz presente na descrição da crise que acometeu Claire e o marido pastor, quando estes, enfrentando diariamente o desafio da crise de sua situação de estrangeiros, depararam-se com sua casa em chamas. Novamente, a força necessária para o enfrentamento da situação foi encontrada na "Providência" divina:

Nós ainda tínhamos um ao outro, e tínhamos ainda o nosso Deus. Nesse momento senti que foi Ele quem, por amor, nos havia tomado nossos bens terrestres, para que o coração aprendesse a perseguir o bem melhor. Eu fiquei mais calma e, intimamente mais controlada, pude caminhar ao longo das ruínas fumegantes, em direção à casa da escola. Só que então tivemos uma agradável surpresa, pelas ali amontoadas coisas salvas. Havia sido um mal-entendido, de que "nada foi salvo", tanto que reencontramos muitas coisas, que, peça a peça, saudamos como novos presentes, um motivo para agradecermos a Deus.

Observa-se neste relato que uma intensa vivência de fé fez com que Claire se conformasse com o incêndio e redirecionasse o seu olhar para que, naquela situação 
de perda, ela valorizasse a preservação do que tinha: o vínculo com o pastor, a vida de ambos e ainda alguns objetos materiais que tinham sido salvos das chamas.

Em carta datada de setembro de 1887, escrita para seus pais, Claire menciona o ocorrido e a interpretação por ela feita diante da situação do incêndio, demonstrando confiança em Deus no que se refere ao presente - literalmente, destruído, e ao futuro que virá:

Hoje o Senhor nos atingiu severamente. Nós estivemos ausentes por 2 dias numa pequena viagem, e, ao retornarmos, encontramos nossa casa queimada até a base. (...) Nós reconhecemos ambos, que: Este castigo nos era muito necessário para nossa humilhação, para recordar-nos de que nosso Salvador requer o coração por inteiro, não dividido. Sim, nós bem reconhecemos isto inteiramente, e pedimos perdão a Ele, enquanto ao mesmo tempo agradecemos a Ele, que nos tenha deixado tanta coisa. Ele é muito misericordioso. Nós confiamos em que Ele também cuidará de novo para o futuro, dando-nos o nosso pão de cada dia e alguma vez novamente uma casa. Agora nós estamos morando em nosso salão, que naturalmente não tem paredes perfeitamente fechadas e nem assoalho e teto.

"O Senhor é meu Pastor..."

Nós pedimos muito sua oração por nós, pois o coração fraco necessita dela.

Parafraseando a própria Bíblia, Claire investe em sua crença para superar a perda, pedindo aos pais o reforço nas orações, para que Deus os ampare e auxilie nesta vivência difícil e aflitiva.

Em outro contexto, discorrendo em suas memórias acerca do Natal na selva, Claire descreve vivências afetivas e a percepção de diferentes horizontes de temporalidade, relata a saudade dos familiares e as lembranças da festa passadas em território europeu, mas conclui que embora distante geograficamente, é o mesmo Deus que se celebra em todos os continentes do mundo:

Quando então ressoaram os cânticos de natal das crianças, do coral da comunidade, com acompanhamento de harmônio e de violinos; quando foi lida a antiquíssima e sempre nova história do nascimento do Salvador; quando as crianças, com olhos brilhantes, vinham à frente para, de acordo com a idade, declamar uma frase ou um verso, podíamos esquecer que vivíamos na selva. Não era o mesmo Deus a quem festejávamos nessa noite, tanto na velha como na nova pátria?

Embora imersa em lembranças de Natais pregressos, quando se entrou no clima natalino, a autora compreendeu que a essência da festa estaria preservada independente do território em que se encontrava. E uma vez convencida da proteção transcendental que a acompanhava, Claire relatava as adversidades vividas e as conquistas feitas sob a ótica de uma filha amparada pelo Pai: 
Graças a Deus não nos falta nada. (...) E se Mamãe em Berlim perguntar: "Então, do que é mesmo que vocês vivem?", então eu poderei the dizer que nós somos filhos bem mimados por Deus. Depender diretamente de Deus é muito melhor do que dos homens. A gente se sente muito mais protegido. $E$ com isto estamos muito felizes e nos queremos muito bem.

Neste trecho de uma carta escrita em março de 1888 para seus pais, Claire recomenda que a mãe não se preocupe com relação a seus ganhos e à sua subsistência, declarando que a dependência direta de Deus garante muito mais proteção do que a dependência de outros homens. Através de sua vivência de fé, tranquiliza os familiares distantes, envolvendo-os em sua certeza da presença divina.

Para Schütz (2010), a adaptação do estrangeiro no grupo novo que o acolheu acontece através do processo contínuo de indagação da nova realidade, que, se tiver sucesso, se tornará para o recém-chegado um abrigo, uma proteção. Claire passou por este processo e encontrou as respostas às suas questões traçando o caminho que leva a Deus. Recorrendo ao seu Salvador, se salvou. Em terras sagradas não há estrangeiros. Todos são iguais. Foi transitando por este espaço invisível da fé que Claire elaborou suas questões e foi assim que ela deixou de se sentir estrangeira. Reconhecendo o mesmo elemento sagrado em ambas as realidades - o mesmo Deus deixado na Alemanha com seus familiares, mas reconhecido no Brasil junto dela e do novo grupo do qual se aproximou.

\section{Considerações finais}

Nas cartas e nas memórias de Claire Lange foram encontrados, concomitantemente às afirmações do estudo de Schütz, relatos de vivências passíveis de análise através da proposta de Husserl apropriada por Edith Stein, que foram abordadas neste trabalho pelo olhar complementar de autoras como Ales Bello e Cardoso. Dentre elas emergiram vivências tais como a perceptiva, vivências afetivas, vivências de temporalidade e vivências espirituais de fé. É se entregando à fé que Claire supera as crises que se colocaram em seu caminho. A autora das cartas descreve através da vivência de novas percepções, sentimentos e emoções, as experiências de rompimento com as expectativas criadas, presentes nos momentos de dúvida e indagação, nas situações de inadequação frente à realidade. Deslocada de seu ambiente passado, perdida na "selva", Claire se rendeu à sua religiosidade e ao encontro que a impulsionou ao longo de sua existência para frente: o encontro com Deus. Pode-se observar que a religião foi, para Claire, um elo de redenção. Desde suas primeiras memórias, até suas últimas cartas contêm seu registro de fé. Foi o 
recurso por ela utilizado para enfrentar a saudade, a ausência, a crise e a dor. A fé registrada nas correspondências, respondida e confirmada por pedidos de orações aos familiares, recomendações a Deus, esperanças de reencontro e descanso além da vida.

Os relatos de Claire confirmam o estudo de Schütz acerca da experiência do estrangeiro e demonstram uma gama ampla de vivências assinaladas por Edith Stein, inclusive a vivência espiritual da fé - utilizada por Claire como mecanismo para superar a crise instaurada por sua condição de estrangeira no Brasil. E lançam uma nova hipótese no que tange à adaptação no novo mundo que se apresenta diante do seu olhar: seria a vivência da relação com a Alteridade capaz de sustentar os impactos pelos quais passa o estrangeiro e promover a superação da experiência de desamparo presente na vivência da crise? O fenômeno desvelado nos registros de Claire Lange demonstra que sim. Que é possível se aproximar da nova realidade, observá-la, entrar em crise devido a um pensamento disfuncional, saltar da plateia para o palco, enfrentar o campo de aventuras no qual consiste a nova realidade e transformar o novo padrão cultural em caráter ambiental quando se mantém a relação com os outros e com o Outro. É possível superar a crise quando se escrevem cartas repletas de saudades e quando se recebem respostas: testemunhos de laços criados na pátria distante, relatos de amor e de afeto, confissões de lembranças compartilhadas no passado. É possível superar a crise uma vez que se permite ser conduzido por Deus e se enxerga a sua presença invisível pelo caminho. É possível ser estrangeiro e resolver as suas questões, reconstruir seus paradigmas e adaptar-se à nova realidade quando esta realidade traz junto de si a certeza inabalável da constância de uma outra Presença.

A análise das cartas e das memórias de Claire apontam para a possibilidade de superação da crise imposta ao estrangeiro através do compartilhamento de vivências com as pessoas deixadas na pátria e com o Deus trazido junto de si. É no encontro com o outro que Claire se reencontra, supera a crise que a acometeu e se situa enquanto estrangeira no país em que chegou.

\section{Referências}

Adami, L. S. (Org.). (2003). Testemunho de fé: memorial do pastor Wilhelm Gottfried Lange. Blumenau, SC: Nova Letra.

Alencastro, L. F. \& Renaux, M. L. (1997). Caras e modos dos migrantes e imigrantes. Em L. F. Alencastro (Org.). História da vida privada no Brasil - Império: a corte e a modernidade nacional. São Paulo: Companhia das Letras. 
Ales Bello, A. (2004). Fenomenologia e ciências humanas: psicologia, história e religião (M. Mahfoud \& M. Massimi, Org. e Trad.). Bauru, SP: Edusc.

Alvim, Z. (1999). Imigrantes: a vida privada dos pobres do campo. Em N. Sevcenko (Org.). História da vida privada no Brasil - República: da belle époque à era do rádio. São Paulo: Companhia das Letras.

Cardoso, C. R. D. (2014). Contribuições de Edith Stein para a psicologia científica. Curitiba: Appris.

Cardoso, C. R. D. (2016). A psique entre a natureza e a cultura em Edith Stein e William Stern. Tese de doutorado, Pós-Graduação em Psicologia, Faculdade de Filosofia, Ciências e Letras de Ribeirão Preto, Universidade de São Paulo, Ribeirão Preto, SP.

Massimi, M. (2016). Saberes psicológicos no Brasil. Curitiba: Juruá.

Schütz, A. (2010). O estrangeiro: um ensaio em psicologia social. Revista Espaço Acadêmico, 113, 117-129.

Stein, E. (2018). Ser finito e ser eterno (Z. C. Crepaldi, Trad.). São Paulo: Forense Universitária. (Original de 1936; publicação póstuma em 1950).

\section{Nota sobre as autoras}

Marcela Elias Santos Gonçalves é mestranda do Programa de Pós-Graduação em Psicologia, área de concentração Processos culturais e Subjetivação, da Faculdade de Filosofia, Ciências e Letras de Ribeirão Preto da USP - Universidade de São Paulo, sob orientação da Professora Titular Marina Massimi. E-mail: marcelaa_elias@hotmail.com

Marina Massimi é professora titular aposentada do Departamento de Psicologia, Faculdade de Filosofia, Ciências e Letras de Ribeirão Preto, Universidade de São Paulo - Campus de Ribeirão Preto. Atualmente é Professora Senior do Instituto de Estudos Avançados da Universidade de São Paulo e lidera Grupo de Pesquisa "Tempo, Memória e Pertencimento" junto ao IEA. E-mail: mmassimi3@yahoo.com 